\title{
Iron bioavailability of Lupinus rotundiflorus seeds and roots in low-iron-diet treated rats
}

\author{
Biodisponibilidade do ferro das sementes e raízes \\ do Lupinus rotundiflorus em ratos tratados \\ com uma dieta de baixo teor de ferro
}

\author{
Elia Herminia VALDÉS MIRAMONTES ${ }^{1}$ \\ Antonio LÓPEZ-ESPINOZA ${ }^{1}$ \\ Alma Gabriela MARTÍNEZ MORENO ${ }^{1}$ \\ Juan Francisco ZAMORA NATERA ${ }^{2}$ \\ Ramón RODRÍGUEZ MACIAS² \\ Mario Alberto RUIZ-LOPEZ ${ }^{2}$
}

\section{A B S T R ACT}

\section{Objective}

To evaluate iron bioavailability of roots and cooked seeds of Lupinus rotundiflorus for human consumption using a low-iron-diet rat model.

\section{Methods}

A hemoglobin depletion-repletion test was performed using rats. A standard diet containing $8 \mathrm{mg} \mathrm{kg}-1$ of iron was used. Three experimental diets were prepared based on the standard diet: $2.3 \mathrm{~g}$ of root flour added to D1, $21.5 \mathrm{~g}$ cooked seed flour added to D2, and $0.03 \mathrm{~g}$ of ferrous sulfate added to D3 (control diet), adjusting iron concentration of the diets to $24 \mathrm{mg} \mathrm{kg}-1$. Hemoglobin regeneration efficiency was used to measure iron bioavailability.

\footnotetext{
1 Universidad de Guadalajara, Centro Universitario del Sur, Centro de Investigación en Comportamiento Alimentario y Nutrición. Guadalajara, Jalisco, México.

2 Universidad de Guadalajara, Centro Universitario de Ciencias Biológicas y Agropecuarias, Departamento de Botánica y Zoología. Camino Ing. Ramón Padilla, 2100, Predio Las Agujas, Nextipac, Zapopan, Jalisco, México. Correspondência paral Correspondence to: MA RUIZ-LOPEZ. E-mail: <mruiz@cucba.udg.mx>.

Article based on the doctoral thesis of EH VALDÉS-MIRAMONTES, entitled "Contenido de fibra dietetica, minerals $y$ biodisponibilidad de hierro en cinco especies de Lupinus del estado de Jalisco". Universidad de Guadalajara; 2016.
} 


\section{Results}

Hemoglobin regeneration efficiency showed values of $13.80+2.49 \%, 13.70+1.60 \%$ and $18.38+1.56$ in D1, D2 and D3 respectively, and biological relative values of $72.8,75.08$, and $100.00 \%(p<0.05)$.

\section{Conclusion}

Roots and cooked seeds of Lupinus rotundiflorus showed potential iron bioavailability, despite being a vegetal source, which could also encourage the study of other species of lupin as a source of iron.

Keywords: Anemia. Biological availabity. Hemoglobin regeneration. Iron.

\section{R E S U M O}

\section{Objetivo}

Avaliar a biodisponibilidade do ferro das semente e raízes cozidas de Lupinus rotundiflorus para humanos usando um modelo de rato com deficiência de ferro.

\section{Métodos}

Um teste de depleção-repleção de hemoglobina foi feito usando ratos. Uma dieta base com $8 \mathrm{mg} \mathrm{kg}-1 \mathrm{de}$ ferro foi usada. Partindo da dieta base, três dietas experimentais foram preparadas: D1 com 2,3g de farinha de raiz adicionada, D2 com 21,5g de farinha da semente cozida adicionada e D3 com 0,03g de sulfato ferroso adicionado (dieta controle), ajustando a concentração de ferro das dietas a 24mg kg-1. A eficiência da regeneração da hemoglobina foi usada para medir a biodisponibilidade do ferro.

\section{Resultados}

Regeneração da hemoglobina apresenta valores de 13,80+2,49\%, 13,70+1,60\% e 18,38+1,56 na D1, D2 e D3 respectivamente e, valores biológicos relativos de 72,8, 75,08 e 100,00\% (p<0.05).

\section{Conclusão}

As raízes e sementes cozidas do Lupinus rotundiflorus mostraram potencial biodisponibilidade de ferro, apesar de ser uma fonte vegetal, que poderia também incentivar o estudo de outras espécies de lupino como uma fonte de ferro.

Palavras-chave: Anemia. Disponibilidade biológica. Hemoglobinas. Ferro.

\section{INTRODUCTION}

Iron deficiency anemia is a common nutritional disorder in humans [1]. Iron deficiency is associated with low iron intake in developed countries, while in developing countries, it could be caused by low iron availability due to absorption inhibitors present in vegetable foods [2-4].

Strategies to reduce iron deficiency have been reported, such as: iron supplements, popular fortification of food products with iron, and different sources of dietary iron.

Thus, legume seeds are a good source of minerals, including iron, however they contain antinutritional factors (mainly oxalates and phytates), which negatively affect iron bioavailability due to the interactions they produce during digestion and absorption [5-8].

Iron can be present in a heme form with relatively high bioavailability which can be found in red meat as part of hemoglobin and myoglobin, but it has also been reported in plants, particularly cereals, nuts, and legumes [2].

Iron in legumes is a structural part of leghemoglobin (rich in heme-iron), which is a protein homologous to hemoglobin and it is most abundant in legume nodules; however, bioavailability in these plant sources has been rarely assessed $[2,8]$.

Lupinus are legumes that have been currently receiving considerable interest as a potential source for food ingredients. Countries 
such as Australia, Poland, Germany, Chile, and Ecuador cultivate L. albus, L. angustifolius, L. luteus and L. mutabilis and consume mainly their seeds [9], incorporating them into different foods for humans or animals $[10,11]$.

There are about 100 species of Lupinus in Mexico, which are widely distributed throughout the country, representing great potential due to the high protein content in the seed, 30-40\%; and oil, 8-12\%, depending on the species, variety, and environmental conditions [12]. However, its use is limited due to quinolizidine alkaloids that make the seed bitter and toxic. However, up to $95 \%$ of these compounds can be removed by boiling $[13,14]$.

Due to the aforementioned, the aim of this study was to evaluate the iron bioavailability in roots and cooked seeds of $L$. rotundiflorus for human consumption using an iron-deficient rat model.

\section{METHODS}

Whole plants of $L$. rotundiflorus in fructification were harvested by hand in Jalisco, Mexico, in August 2015. Specimens were botanically identified and deposited at the Herbario del instituto de Botánica de la Universidad de Guadalajara, Mexico.

Mature seeds and whole roots with nodules were separated, $500 \mathrm{~g}$ of seeds were boiled in water (ratio 1:5 w/v) at atmospheric pressure for 3 hours, with water replenishment, $500 \mathrm{~g}$ of roots were washed with deionized water to remove soil residues, dried at $55^{\circ} \mathrm{C}$ for 48 hours in a forced-air stove, and ground to obtain a flour with particle size of $0.5 \mathrm{~mm}$ in diameter for chemical analysis $(n=3)$ and assessment of bioavailability.

The flour of the cooked seeds, roots, and diets were analyzed using the techniques of Association of Official Analytical Chemists [15]. The crude fat, crude protein, ash, and Total Dietary Fiber (TDF) content were analyzed by the enzymatic-gravimetric method. Total iron content was determined by flame atomic absorption (GBC-AVANTA, GBC Scientific Equipment Ltd., Dandenong, Victoria, Australia) in which the ash samples were diluted in an acid solution.

For the iron bioavailability test, a AIN-93G (standard diet) with no added iron $1 / 2$ IRR with iron content lower than 8 ppm was obtained from TestDiet, manufactured in Richmond, Indiana, United States $[15,16]$.

Three experimental diets were prepared based on the standard diet: Diet one (D1) consisted of $2.3 \mathrm{~g}$ of $\mathrm{L}$. rotundiflorus root flour added to $100 \mathrm{~g}$ of standar diet; Diet two (D2) of $21.5 \mathrm{~g}$ of $\mathrm{L}$. rotundiflorus cooked seed flour added to $100 \mathrm{~g}$ of standard diet; while Diet three (D3) consisted of only $0.03 \mathrm{~g}$ of ferrous sulfate $\left(\mathrm{FeSO}_{4} 7 \mathrm{H}_{2} \mathrm{O}\right)$ added to standar diet, which was considered the control diet. The amount of iron added to the standard diet content was adjusted to each of the iron sources and, once the analysis was performed, the results of the Fe concentration showed final concentrations of $24 \mathrm{mg} \mathrm{kg}^{-1}$ in diets, which is similar to the one required for rats on weaning and growth [17]. Food and deionized water was available ad libitum (Table 1).

Analysis of iron bioavailability was performed using a hemoglobin depletionrepletion assay [15] in 36 male Wistar rats aged 21 to 23 days, housed in the vivarium of the Centro de Investigaciones en Comportamiento Alimentario y Nutrición, Centro Universitario del Sur de la Universidad de Guadalajara. The handling of the rats was approved by the Behavior Research Center in Food and Nutrition ethics committee. The animals were weighed and placed in individual polycarbonate cages with a stainless-steel lid, in a controlled environment with a 12 hours light-dark cycle at $22^{\circ} \mathrm{C}$. At the beginning of the experiment, five milliliters of blood were extracted from each rat by tail incision to determine the hemoglobin and hematocrit concentration value using the automated hematology analyzer Celly-70 Biocode Haycel. 
Table 1. Composition of diets.

\begin{tabular}{lcccc}
\hline Ingredients $(\mathrm{g})$ & Standard diet & D1 & D2 & D3 \\
\hline Cornstarch & 39.75 & 39.75 & 39.75 & 39.75 \\
Casein - vitamin free & 20.00 & 20.00 & 20.00 & 20.00 \\
Maltodextrin & 13.20 & 13.20 & 13.20 & 13.20 \\
Saccharose & 10.00 & 10.00 & 10.00 & 10.00 \\
Soy oil & 7.00 & 7.00 & 7.00 & 7.00 \\
Powdered cellulose & 5.00 & 5.00 & 5.00 & 5.00 \\
AIN-93G Min PX/no iron added & 3.50 & 3.50 & 3.50 & 3.50 \\
AlN-93 vitamins mix & 1.00 & 1.00 & 1.00 & 1.00 \\
L-cystine & 0.30 & 0.30 & 0.30 & 0.30 \\
Bitartrate & 0.25 & 0.25 & 0.25 & 0.25 \\
t-butylhydroquinone & 0.001 & 0.001 & 0.001 & 0.001 \\
L. rotundiflorus root flour $_{\text {L. rotundiflorus cooked seed flour }}$ & & 2.3 & - & - \\
FesO & 7H & & \\
\hline
\end{tabular}

Note: D1: Roots of $L$. rotundiflorus added to standard diet; D2: Cooked seeds of $L$. rotundiflorus added to standard diet; D3: Ferrous sulfate added to standard diet.

During the depletion period, the rats consumed the standard diet (AIN-93G), (iron lower than 8ppm) ad libitum. Each week, the hemoglobin of blood was verified to determine if the animals were anemic $(<6 \mathrm{~g} / 100 \mathrm{~mL})$. Anemia was achieved after five weeks. Their weight and food consumption were individually recorded daily.

After the rats were depleted, the repletion period began. The rats were divided into three groups of 12 rats according to weight (similar weight average). Each group received a diet; D1, D2 and D3, respectively. During this period, weight and food consumption was recorded daily and hemoglobin concentration was monitored weekly until a normal level was obtained $(11 \mathrm{~g} / \mathrm{dL}$ to $18 \mathrm{~g} / \mathrm{dL}$ ), which took three weeks.

The percentage of iron bioavailability was calculated by the Hemoglobin Regeneration Efficiency (HRE) as the percentage of iron intake retained in hemoglobin: $\operatorname{HRE}(\%)=[(\mathrm{HbFefinal}-$ HbFeinitial) $x$ 100] / InFe To. Hb Fefinal is the iron concentration in the hemoglobin of the rats at the end of the repletion period. HbFeinitial is the iron concentration in the hemoglobin of the rats at the beginning of the repletion period, and InFe To is the total iron intake of the rats during the repletion period, which was calculated as the product of the dietary iron concentration according to the amount of food each animal consumed during the experiment. HbFe was calculated considering a quantity of $0.067 \mathrm{~mL}$ of blood/g rat body weight and hemoglobin iron content of $3.4 \mathrm{mg} \mathrm{Fe} / \mathrm{g} \mathrm{Hb}$. HbFe = Body weight (g) $\times \mathrm{Hb}(\mathrm{g} / \mathrm{L} \times 0.067 \mathrm{~mL} / \mathrm{g} \times 3.4 \mathrm{mg} \mathrm{Fe} / \mathrm{g} \mathrm{Hb} 4[4,18])$.

Biological Relative Value (BRV) expresses the use of an iron source relative to the standard reference $\left(\mathrm{FeSO}_{4} 7 \mathrm{H}_{2} \mathrm{O}\right.$ ), which is calculated by dividing the HRE of the analyzed compound (D1 and D2) between the diet controls HRE (D3) $\times 100$.

Statistical analysis of the three treatments of bioavailability was performed using Analysis of Variance and Tukey test. The Student's t-test was used to compare the differences between the initial and final $\mathrm{Hb}$ concentration means of each treatment during the repletion and the statistical software JMP ${ }^{\circledR}$ (SAS Campus Drive Cary, North Carolina, United States) was used to compare the values analyzed between the two periods. 


\section{RES U L T S}

Analysis of the chemical composition and iron content of the roots and cooked seeds of L. rotundiflorus, and, D1, D2, and D3 diets are shown in Table 2.

The protein content of the cooked seeds of $\mathrm{L}$. rotundiflorus was higher than the whole roots $(37.52 \pm 0.24$ and $10.15 \pm 0.27 \mathrm{~g} / 100 \mathrm{~g}$ of dry base, respectively). Similarly, the fat value was higher in cooked seeds than in the roots $(6.26 \pm 0.08$ and $0.3 \pm 0.03 \mathrm{~g} / 100 \mathrm{~g})$.

Nevertheless, ash and TDF content was higher in whole roots $(6.3 \pm 0.14$ and $70.7 \pm 027 \mathrm{~g} / 100 \mathrm{~g})$ than in the cooked seeds (3.04 \pm 0.1 and $27.4 \pm 0.4 \mathrm{~g} / 100 \mathrm{~g}$, respectively).

Iron concentration in cooked seeds of the species studied was $61.2 \pm 4.2 \mathrm{mg} / \mathrm{kg}$, however, the Fe content in the root was much higher $(700 \pm 6.0 \mathrm{mg} / \mathrm{kg}$ ).

The diets, protein, and TDF contents of $\mathrm{g} / 100 \mathrm{~g}$ of the dry matter of standard diet $(18.3 \pm 0.32$ and $5.0 \pm 0.1), D 1(17.0 \pm 0.12$ and $6.83 \pm 0.02)$, and D3 (18.3 $\pm 0.145 .0 \pm 0.13)$ were similar. However, in D2 these nutrients were higher (24.0 \pm 0.56 and $10.0 \pm 0.08)$. Fat and ash contents $(7.1 \pm 0.17$ and $1.6 \pm 0.1)$ were similar in all standard diets: D1 (7.08 \pm 0.17 and $2.0 \pm 0.07)$; D2 (6.9 \pm 0.1 and $1.96 \pm 0.1)$; and D3 $(7.1 \pm 0.1$ and 1.6 \pm 0.06$)$, respectively. D1, D2 and D3 were adjusted to $24.0 \mathrm{mg} / \mathrm{kg}$ of iron.

Table 3 shows the initial and final weight, food intake, and mean weight gain during the depletion and repletion periods. The initial and final mean weights during the depletion period were $90.33+27.09$ and $219.01+26.28 \mathrm{~g}$, with a

Table 2. Chemical composition and iron content of cooked seeds and roots of L. rotundiflorus and diets SD, D1, D2 y D3 (dry matter, $n=3$ )

\begin{tabular}{lccccc}
\hline Ingredients and diets & Protein $\mathrm{g} / 100 \mathrm{~g}$ & Fat g/100g & Ash g/100g & TDF g/100g & Fe $\mathrm{mg} / \mathrm{kg}$ \\
\hline Whole root & $10.15 \pm 0.27$ & $0.3 \pm 0.03$ & $6.3 \pm 0.14$ & $70.7 \pm 027$ & $700 \pm 6.0$ \\
Cooked seed & $37.5 \pm 0.24$ & $6.26 \pm 0.08$ & $3.04 \pm 0.1$ & $27.4 \pm 0.4$ & $61.2 \pm 4.2$ \\
Standard diet & $18.3 \pm 0.32$ & $7.1 .0 \pm 0.17$ & $1.6 \pm 0.1$ & $5.0 \pm 0.1$ & $8.0 \pm 0.00$ \\
D1 & $17.0 \pm 0.12$ & $7.08 \pm 0.17$ & $2.0 \pm 0.07$ & $6.83 \pm 0.023$ & $24.0 \pm 0.0$ \\
D2 & $24.0 \pm 0.56$ & $6.9 \pm 0.1$ & $1.96 \pm 0.1$ & $10.0 \pm 0.08$ & $24.0 \pm 0.0$ \\
D3 & $18.3 \pm 0.14$ & $7.10 \pm 0.09$ & $1.6 \pm 0.06$ & $5.0 \pm 0.13$ & $24.0 \pm 0.0$ \\
\hline
\end{tabular}

Note: Values are presented as means + standard deviation.

TDF: Total Dietary Fiber; SD: Standard Deviation; D1: Root of L. rotundiflorus added to standard diet; D2: Cooked seeds of L. rotundiflorus added to standard diet; D3: Ferrous sulfate added to standard diet.

Table 3. Initial and final weight, weight gain and total food intake of the different diets during the depletion-repletion periods in rats $(\mathrm{N}=36)$

\begin{tabular}{|c|c|c|c|c|c|}
\hline Periods & Food & Initial weight (g) & Final weight (g) & Weight gain $(\mathrm{g})$ & Average food intake (g/day) \\
\hline Depletion ( $N=36)$ & & $90.33 \pm 27.09$ & $219.01 \pm 26.28$ & $101.24 \pm 13.36$ & $16.95 \pm 0.74$ \\
\hline \multicolumn{6}{|l|}{ Repletion } \\
\hline & D1 & $234.80 \pm 21.07^{*}$ & $308.00 \pm 22.51^{*}$ & $64.16 \pm 13.17^{\mathrm{a}^{*}}$ & $20.23 \pm 2.04^{*}$ \\
\hline & D2 & $211.20 \pm 16.29^{*}$ & $264.79 \pm 32.15^{*}$ & $32.83 \pm 11.02^{\mathbf{b}^{*}}$ & $20.38 \pm 2.44^{*}$ \\
\hline & D3 & $218.20 \pm 26.26^{*}$ & $270.00 \pm 26.98^{*}$ & $30.83 \pm 6.88^{\mathbf{b}^{*}}$ & $20.23 \pm 1.82^{*}$ \\
\hline
\end{tabular}

Note: Values presented as means + standard deviation. Different letters within the same column shows statistical significant differences ( $p<0.05$ ) for each parameter in the repletion period. *Asterisks in the same column for the repletion period indicate statistical significant differences $(p<0.05)$.

D1: Complete root of $L$. rotundiflorus added to standard diet, $(n=12)$; D2: Cooked seeds of $L$. rotundiflorus added to standard diet ( $n=12)$; $D 3$ : Ferrous sulfate added to standard diet $(n=12)$. 
mean weight gain of $101.27+13.36$. The mean food intake was $16.95+0.74 \mathrm{~g} /$ day.

During the repletion period, data showed a statistically significant difference in weight gain between D1 $(64.16+13.17)$ in comparison with D2 (32.83+11.02) and D3 (30.83+6.88).

The rats in D1 showed statistically higher difference $(p<0.05)$ in iron intake $(11.63+0.69 \mathrm{mg})$ in comparison with D3 $(9.24+0.04)$ and D2 $(8.62+0.41)$. Hemoglobin concentration value at the beginning of the repletion period in the three rat groups showed a statistically significant difference $(p<0.05)$ with respect to the final concentration of mean hemoglobin $(6.86+0.50 \mathrm{mg} / \mathrm{dL}$ and $13.39+1.25 \mathrm{mg} / \mathrm{dL})$, respectively. However, hemoglobin showed no statistically significant difference ( $p>0.05$ ) among diets (Table 4).

Iron bioavailability, measured as hemoglobin regeneration efficiency, was statistically higher $(p<0.05)$ in the control diet (D3: 18.38+1.56), followed by D1 (13.80+2.5\%) and D2 (13.70+1.6\%), with no statistically significant differences between these two groups ( $p>0.05$ ).

As for the biological relative value, considering the ferrous sulfate as $100.0 \%$, statistically significant differences were not found between diets with roots and cooked seeds (values of $75.08 \%$ and $72.8 \%$, respectively).

\section{DISCUSSIO N}

The protein content decreases with cooking, as previous studies have reported in the seeds in this specie [19]. Nevertheless, the values found in the present research were higher than the cooked seeds of $L$. mexicanus $(33.1 \mathrm{~g} / 100 \mathrm{~g})$ and lower than the boiled seeds of $L$. montanus (42.2), L. elegans (43.3), L. exaltatus (43.4) and L. campestris $(49.7)[19,14]$.

The fat value of the cooked seeds of L. rotundiflorus is in agreement with other authors [19] who have reported fat values of 5.41 to $8.2 \mathrm{~g} / 100 \mathrm{~g}$ in other cooked seeds of wild lupines. However, fat values in boiled seeds of L. campestris $(13.2 \mathrm{~g} / 100 \mathrm{~g})$ have been reported [14] to be higher than those observed in our study.

The total dietary fiber of cooked seeds in the species in our study was similar to the one found in the raw seeds of the same species (27.9) and higher than in the L. elegans (21.4) and L. montanus (26.1), but lower in the cooked seeds of $L$. mexicanus (28.4) and $L$. exaltatus (33.0) [19]. The value reported in the raw seeds of L. albus was 50.4g/100g [20].

Iron value decreases with heat treatment. A previous study reported that the raw seeds of this species has an iron content of $8.3 \mathrm{mg} / \mathrm{kg}$ [19]. The higher value of $\mathrm{Fe}$ in whole roots is because this part of the plant presents nodules, which are rich in leghemoglobin, a protein rich in iron, due to greater nitrogen fixation activity that facilitates oxygen diffusion. In spite of this, there are few reports on this mineral content in legume roots.

Table 4. Iron intake, initial and final hemoglobin, Hemoglobin Regeneration Efficiency (HRE), and Biological Relative Value (BRV) on depleted rats feed with three different iron sources during the repletion period.

\begin{tabular}{lccccccc}
\hline Diet & Fe Intake $(\mathrm{mg})$ & Initial $\mathrm{Hb}(\mathrm{g} / \mathrm{dL})$ & Final Hb $(\mathrm{g} / \mathrm{dL})$ & Initial HbFe $(\mathrm{mg})$ & Final HbFe $(\mathrm{mg})$ & $\operatorname{HRE}(\%)$ & $\mathrm{BRV}(\%)$ \\
\hline Repletion & & & & & & & \\
D1 & $11.63 \pm 0.6^{\mathrm{a}}$ & $7.20 \pm 1.01^{\mathrm{a}}$ & $13.44 \pm 0.85^{\mathrm{a}}$ & $1.50 \pm 0.25^{\mathbf{b}}$ & $3.12 \pm 0.19^{\mathrm{a}}$ & $13.80 \pm 2.0^{\mathbf{b}}$ & $75.08^{\mathbf{b}}$ \\
D2 & $8.62 \pm 0.41^{\mathrm{c}}$ & $6.56 \pm 0.32^{\mathrm{a}}$ & $12.65 \pm 2.14^{\mathrm{a}}$ & $1.86 \pm 0.22^{\mathrm{a}}$ & $3.04 \pm 0.49^{\mathrm{a}}$ & $13.70 \pm 1.6^{\mathbf{b}}$ & $72.80^{\mathbf{b}}$ \\
D3 & $9.24 \pm 0.04^{\mathbf{b}}$ & $6.83 \pm 0.30^{\mathrm{a}}$ & $14.10 \pm 0.82^{\mathrm{a}}$ & $1.51 \pm 0.07^{\mathbf{b}}$ & $3.21 \pm 0.18^{\mathrm{a}}$ & $18.38 \pm 1.5^{\mathbf{a}}$ & $100.0^{\mathbf{a}}$ \\
& & $\mathrm{X}=6.86+0.5$ & $\mathrm{X}=13.39+1.25$ & & & & \\
\hline
\end{tabular}

Note: Different letters in the same column show significant differences $(p<0.05)$. Fe in $\mathrm{Hb}$ was calculated: $\mathrm{mg} \mathrm{Fe}$ in $\mathrm{Hb}=($ weight $\times \mathrm{Hb} \times 0.067$ $x$ 3.4). \%HRE $=[\mathrm{Fe} \mathrm{Hb}($ final) $-\mathrm{Fe} \mathrm{Hb}$ (initial) $\times 100] / F e$ Intake $(\mathrm{mg}) . \% B R V=H E R(D+R$ o D+S) / ERH (SF).

D1: Complete root of L. rotundiflorus added to standard diet; D2: Cooked seeds of L. rotundiflorus added to standard diet; D3: Ferrous sulfate added to standard diet. 
On the other hand, the higher protein value in D3 is because more cooked seeds of L. rotundiflorus were used (which is richer in protein) to adjust the iron content.

The results found in a bioavailability study [21] were lower than the ones reported here because the initial weight was $152.57 \pm 2.48$ and final weight was $161.90 \pm 26.79$, thus there was lower weight gain $(9.33 \pm 4.37)$, but food intake was higher $(28.00 \pm 2.62 \mathrm{~g} /$ day $)$ in the depletion period. The data differs from ours due to the difference in the age of rats (as the rats were older in the that study) as well as a different initial weight and duration of depletion period, since the study period lasted three weeks, while ours lasted five weeks [21].

In the repletion period, the difference in weight gain in D1 could have been because the initial and final weights of the group were higher (Table 3). The values found in the present study were lower than those found in another study [20], which reported a mean weight gain of 64 to $80 \mathrm{~g}$ during the three-week repletion period, using the same standard diet, probably because the rats were of a different strain and the repletion period started at a different age.

A hemoglobin concentration of 6.33 to $7.88 \mathrm{mg} / \mathrm{dL}$ at the beginning of the repletion period and 14.00 to $14.60 \mathrm{mg} / \mathrm{dL}$ at the end of repletion period was observed in rats submitted to two dietary treatments with a standard diet with ferrous sulfate or micronized iron [20], which presented data similar to the ones obtained in our study.

Iron bioavailability of 10.02 to $20.55 \%$ for ferrous sulfate was also reported [21], similar to the one found in present study. Similarly, iron bioavailability of $11.40+1.4 \%$ was reported in cowpea seeds (Vigna unguiculata) submitted to thermal treatment (steaming for 10 minutes) [22], a value lower than the one obtained in our study for the cooked seeds of $L$. rotundiflorus. However, other authors [5] have reported higher values than those found in this study for cooked beans and soybeans ( $21.9 \%$ and $19.9 \%$, respectively).
The biological relative value have a good bioavailability because legume roots generally do not contain substances that interfere with iron availability, such as phytates and oxalates, as it has been reported that these substances preferentially accumulate in legume seeds.

With regard to the iron bioavailability of $28+10 \%$ reported in soybean root nodules and leghemoglobin bioavailability of $19+17 \%$, with a BRV of 125 and 113, respectively [2], in comparison to the ferrous sulfate (considered as $100 \%$ ). It has also been shown that thermal treatments in legume seeds eliminate mineral absorption inhibition factors and denaturalize protein molecular structure, increasing their bioavailability $[5,8]$.

\section{CONCLUSION}

Iron concentration was greater in the roots than in seeds. L. rotundiflorus roots, as well as the cooked seeds, showed good bioavailability when compared to the bioavailability rate of non-heme iron, which ranges from 2\%-20\%. If we consider that the amount of iron found in the root nodules of the legume is formed by leghemoglobin, they may be partially purified and incorporated as a source of iron in foods.

\section{CONTRIBUTORS}

All authors were involved in the concept and design of this study. EH VALDÉS-MIRAMONTES was responsible for the development of the experimental phase, preparation of the experimental diets, and analysis of bioavailability. AG MARTíNEZ MORENO participated in training on the handling, provided the rats for the experiment, collected the data, and carried out the nutritional analyses. MA RUIZLOPEZ and A LÓPEZ-ESPINOZA provided substantial contributions to the concept of the study; assessed the quality of study design, and revised the written manuscript. R RODRIGUEZ-MACIAS and JF ZAMORANATERA collected, selected the samples of the Lupin species, and performed statistical analysis. All authors critically reviewed the manuscript and approved the final version submitted for publication. 


\section{REFERE N CES}

1. Zielińska-Dawidziak M, Hertig I, Staniek H, Piasecka-Kwiatkowska D, Nowak KW. Effect of iron on the absorption of metal ions from plant ferritin. Plant Foods Hum Nutr. 2014;69(2):101-7. https://doi.org/10.1007/s11130-014-0413-1

2. Suliburska J, Zbigniew K. Evaluation of the content and bioaccessibility of iron, zinc, calcium and magnesium from groats, rice, leguminous grains and nuts. J Food Sci Technol. 2014;51(3):589-94. https://doi.org/10.1007/s13197-011-0535-5

3. Garcia Y, Gonzalez R, Menendez R, Gonzalez $M$, Bourg V. Effect of supplementation with dehydrated formulation of heme iron + iron ion in rats. J Food Nutr. 2008;18:204-12.

4. Salgueiro MJ, Arnoldi S, Torti H, Collia N, Fuda J, Weill R, et al. Bioavailability of Stabilized Iron (II) sulfate in an industrialized fortified infant dessert. Studies in rats by means of the prophylactic: Preventive method. Open Nutraceuticals J. 2009;5(2):1-3. https://doi.org/10.2174/18763960 00902010001

5. Chitra U, Singh U, Rao PV. Effect of varieties and processing methods on the total iron and ionizable contents of grain legumes. J Agric Food Chem. 1997;45(10):3859-62. https://doi.org/10.1021/jf97 $0073 a$

6. Sahuquillo A, Barbera R, Farré R. Bioaccessibility of calcium, iron and zinc from three legume samples. Nahrung. 2003;47(6):438-41. https:// doi.org/10.1002/food.200390097

7. Binaghi M, Managing MJ, Greco CB, Lopez LB, Ronayne PA, Valencia ME. Bioavailability of iron in children's diets. Argen Arch Pediatr. 2008; 106(5):387-9.

8. Yossef $H$. Effect of calcium and phosphorus nonhaeme on iron absorption in rats and haematogenic characteristics. Food Nutr Scienc. 2010;1(1):13-8. https://doi.org/10.4236/fns.2010. 11003

9. French RF, Shea $G$, Buirchell $B$. Introduction and history. In: White P, French B, McLarty A, editors. Producing lupins. Bulletin $n^{\circ}$ 4720. Perth: Department of Agriculture and Food; 2008 [cited 2008 Sept 14]:11-8. Available from: http:// researchlibrary.agric.wa.gov.au/cgi/viewcontent. cgi? article $=1009 \&$ context=bull

10. Sipsas S. Lupin products-concepts and reality. In: Palta JA, Berger JB, editors. Lupins for health and wealth. Proceedings of the 12th International Lupin Conference; 2008 Sept. 14-18; Fremantle, Australia. Perth: Department of Agriculture and Food; 2008 [cited 2008 Sept 14]. p.506-13. Available from: https://www.cabdirect.org/cabdirect/ abstract/20103116839

11. Nasar-Abbas SM, Jayasena V. Effect of lupine flour incorporation on the physical and sensory properties of muffins. Qual Assur Saf Crop.
2012;4(1):41-9. https://doi.org/10.1111/j.1757-83 7X.2011.00122.X

12. Ruiz-Lopez MA, Rodriguez-Macias $R$, Perez NS. Chemical nutritional evaluation of Lupinus exaltatus Zucc, the Nevado de Colima, Mexico as a potential source of fodder. Interciencia. 2006;31(10):758-60.

13. Mohammed MA, Mohamed EA, Yagoub AEA, Mohamed AR, Babiker EE. Effect of processing methods on alkaloids, phytate, phenolics, antioxidants activity and minerals of newly developed lupin (Lupinus albus L.) Cultivar. J Food Process Preserv. 2017;41(1):e12960. https://doi. org/10.1111/jfpp. 12960

14. Jimenez-Martinez C, Mora-Escobedo R, Martinez CA, Muzquiz M, Pedroza MM, Dávila-Ortiz G. Effect of aqueous, acid, alkaline and thermal treatments on antinutritional factors content and protein quality in Lupins campestris seed flour. J Agr Food Chem. 2010;58(3):1741-5. https://doi. org/10.1021/jf902688r

15. Association of Official Analytical Chemists. Methods of analysis 20th ed. 2016 Washington (DC): Latimer G.W

16. Farias JS, Suruagy AM, Lima OS, Porto BJ, Rego CC, Melo IS, et al. Dietary intake of AIN-93 standard diet induces fatty liver with altered hepatic fatty acid profile in Wistar rats. Nutr Hosp. 2015;31(5):2140-6. https://doi.org/10.3305/nh.2015.31.5.8597

17. National Research Council. Nutrient requirements of laboratory animals. Washington (DC): National Academic Press; 1995.

18. Forbes AL, Arnaud MJ, Chichester CO, Cook JD, Harrison BN, Hurrell RF, et al. Comparison of in vitro, animal, and clinical determinations of iron bioavailability: International Nutritional Anemia Consultative Group Task Force report on iron bioavailability. Am J Clin Nut. 1989;49(2):225-38.

19. Valdes-Miramontes EH, López-Espinoza A, Rodriguez-Macias R, Salcedo-Perez E, Ruiz-López MA. Effect of heat treatment on the chemical composition and minerals in wild lupine seeds. Rev Chil Nutr. 2015,42(2):186-90. https://doi.org/10. 4067/S0717-75182015000200011

20. Písaríḱková B, Zralý Z. Dietary Fibre Content in Lupine (Lupinus albus L.) and soybean (Glycine max L.) Seeds. Acta Vet Brno. 2010,79(2):211-6. https://doi.org/10.2754/avb201079020211

21. Haro VJ. Different bioavailability of iron compounds added to a functional fruit nectar. Interaction with vitamins and fructo oligosaccharides [thesis]. Murcia: Universidad de Murcia; 2006.

22. Drago SR, Gonzalez RJ, Chel-Guerrero L, Valencia ME. Assessment of the availability of minerals in bean flour and corn mixtures/extruded beans. Inf Tech. 2007;18(1):41-6.

Received: August 2, 2017 Final version: October 19, 2017 Approved: October 30, 2017 